\title{
A microarray study of MPP+-treated PCI 2 Cells: Mechanisms of toxicity (MOT) analysis using bioinformatics tools Zengjun $\mathrm{Xu}^{1}$, Tucker A Patterson ${ }^{1}$, Jonathan D Wren ${ }^{2}$, Tao Han ${ }^{3}$, Leming Shi ${ }^{3}$, Helen Duhart ${ }^{1}$, Syed F Ali ${ }^{1}$ and William Slikker Jr*1
}

\begin{abstract}
Address: ${ }^{1}$ Division of Neurotoxicology, National Center for Toxicological Research, U.S. Food and Drug Administration, 3900 NCTR Road, Jefferson, Arkansas 72079, USA, ${ }^{2}$ Advanced Center for Genome Technology, Department of Botany and Microbiology, 101 David L. Boren Blvd., The University of Oklahoma, Norman Oklahoma 73019, USA and ${ }^{3}$ Division of Systems Biology, National Center for Toxicological Research, U.S. Food and Drug Administration, 3900 NCTR Road, Jefferson, Arkansas 72079, USA

Email: ZengjunXu - axu@genelogic.com; Tucker A Patterson - TPatterson@nctr.fda.gov; Jonathan D Wren - Jonathan.Wren@OU.edu; Leming Shi - leming.shi@fda.hhs.gov; William Slikker* - wslikker@nctr.fda.gov

* Corresponding author
\end{abstract}

from Second Annual MidSouth Computational Biology and Bioinformatics Society Conference. Bioinformatics: a systems approach Little Rock, AR, USA, 7-9 October 2004

Published: 15 July 2005

BMC Bioinformatics 2005, 6(Suppl 2):S8 doi:I0.1 I86/I47I-2105-6-S2-S8

\begin{abstract}
Background: This paper describes a microarray study including data quality control, data analysis and the analysis of the mechanism of toxicity (MOT) induced by I-methyl-4-phenylpyridinium $\left(\mathrm{MPP}^{+}\right)$in a rat adrenal pheochromocytoma cell line ( $\mathrm{PCl} 2$ cells) using bioinformatics tools. MPP+ depletes dopamine content and elicits cell death in PCI2 cells. However, the mechanism of MPP+_ induced neurotoxicity is still unclear.

Results: In this study, Agilent rat oligo 22K microarrays were used to examine alterations in gene expression of $\mathrm{PCl} 2$ cells after $500 \mu \mathrm{M} \mathrm{MPP}^{+}$treatment. Relative gene expression of control and treated cells represented by spot intensities on the array chips was analyzed using bioinformatics tools. Raw data from each array were input into the NCTR ArrayTrack database, and normalized using a Lowess normalization method. Data quality was monitored in ArrayTrack. The means of the averaged log ratio of the paired samples were used to identify the fold changes of gene expression in $\mathrm{PCl} 2$ cells after $\mathrm{MPP}^{+}$treatment. Our data showed that 106 genes and ESTs (Expressed Sequence Tags) were changed 2-fold and above with MPP+ treatment; among these, 75 genes had gene symbols and 59 genes had known functions according to the Agilent gene Refguide and ArrayTrack-linked gene library. The mechanism of MPP+-induced toxicity in PCI 2 cells was analyzed based on their genes functions, biological process, pathways and previous published literatures.
\end{abstract}

Conclusion: Multiple pathways were suggested to be involved in the mechanism of MPP+-induced toxicity, including oxidative stress, DNA and protein damage, cell cycling arrest, and apoptosis.

\section{Introduction}

DNA microarrays have been increasingly applied as a tool for the simultaneous monitoring of relative expression levels of thousands of genes for samples under various conditions, e.g., normal versus disease, and control versus drug or toxicant treatment [1-3], and offer a promising means to better understand how cells react to environmental perturbations. Their popularity, in part, is reflected by the number of microarray-related publications indexed in PubMed, which have been increasing exponentially. 
With the improvement of microarray chip quality and tools for data quality assurance, the focus in this field has gradually switched from determination of the gene numbers with altered expression levels to the analysis of the biological mechanism by categorizing significantly changed genes into functional groups and pathways [5-7]. Toxicogenomics, a emerging field combining genomics and bioinformatics to identify and characterize mechanisms of toxicity (MOT) for drugs and various compounds, has been developed quickly during the last several years [8-13]. Microarrays, with their power to examine genome-wide transcriptional responses, have become a key technology in toxicogenomics.

During the last two decades, MPTP (1-methyl-4-phenyl1,2,5,6-tetrahydropyridine) - induced neurotoxicity has attracted a great deal of attention because of the similarity of its toxic effects to the biochemical changes in the brains of patients with Parkinson's disease (PD) [14,15]. PD is a progressive neurodegenerative disorder that results in degeneration of dopaminergic neurons in the substantia nigra (SN) and dopamine depletion in the striatum [16]. Although MPTP does not exactly reproduce PD, it has been an extremely valuable tool to model many features of PD in animals, and has led to a better understanding of crucial aspects of the sub-cellular events participating in the evolution of the PD clinical syndrome and neurotoxicity [17-20]. In order to be active, MPTP requires monoamine oxidase $\mathrm{B}$ to be converted into $\mathrm{MPP}^{+}(1-$ methyl-4-phenylpyridinium) [21]. $\mathrm{MPP}^{+}$is selectively taken up by dopaminergic neurons via the dopamine transporter of the plasma membrane $[22,23]$ and produces neuronal loss in substantia nigra (SN), striatal dopamine (DA) depletion and behavioral impairments in humans [24], primates [14], and mice [15,25-28].

PC12 cells, a rat clonal pheochromocytoma cell line [29], possess dopamine synthesis, metabolism and transporter systems [30-32], and therefore have been used as a model for studies of $\mathrm{MPP}^{+}$neurotoxicity and $\mathrm{PD}$. A plethora of evidence has demonstrated that $\mathrm{MPP}+$ depletes dopamine and elicits cell death in PC12 cells [33-36]. Previously, we demonstrated that $\mathrm{MPP}^{+}$-induced $\mathrm{DA}$ depletion and cell loss in PC12 cells is dose and time-course responsive [37]. However, the mechanism of $\mathrm{MPP}^{+}$neurotoxicity in PC12 cells is still unclear. Generally, it is believed that MPP+ directly and/or indirectly inhibits mitochondrial complex I, causing abnormal energy metabolism and increased production of reactive oxygen species (ROS), resulting in cell death $[34,36,38]$. Our study indicated that $\mathrm{MPP}^{+}$may compromise heat shock protein (HSP) cell defense systems and cause apoptosis in NGF-differentiated PC12 cells and C56, but not CD1, mice $[37,39]$. However, some studies have suggested that the effect of $\mathrm{MPP}^{+}$on PC12 cells might be independent of ROS [35,40]. Recent studies have also demonstrated that endoplasmic reticulum [41], PI-3 [42] and cAMP pathways [43] may be possible targets for $\mathrm{MPP}^{+}$-induced neurotoxicity. Thus, $\mathrm{MPP}^{+}$may cause PC12 cell injury and death via multiple complex mechanisms. Therefore, DNA microarray analysis, by measuring the expression of large numbers of genes, is a promising tool to help elucidate the mechanism of $\mathrm{MPP}^{+}$-induced toxicity in PC12 cells.

With the development of bioinformatics, various toxicogenomic databases and bioinformatics tools are available for data manipulation and mining $[9,44,45]$. The Center for Toxicoinformatics in the FDA's National Center for Toxicological Research (NCTR/FDA) has developed a public microarray data management and analysis software, called ArrayTrack, for FDA-wide microarray data storage and preliminary data analysis $[10,46]$. In this study, alterations of gene expression were examined using the Agilent microarray platform and the data were analyzed using ArrayTrack and a software package called IRIDESCENT.

\section{Methods and materials Cell culture and MPP+ treatment}

PC12 cells at passage 15-20 (ATCC, Manassas, VA) were grown in $75 \mathrm{~cm}^{2}$ tissue culture flasks at $37^{\circ} \mathrm{C}$ under an atmosphere of $5 \% \mathrm{CO}_{2} / 95 \%$ air in RPMI 1640 medium (Sigma, St. Louis, MO) containing $10 \%$ horse serum and $5 \%$ fetal bovine serum (complete media). At about $80 \%$ confluence, cells were placed into 24 -well plates and cultured for another 2 days, and then were treated with 500 $\mu \mathrm{M}$ MPP+ iodide (Sigma, 100\% purity by HPLC), a dose that induces significant decrease in dopamine content and cell viability [37].

\section{RNA Isolation}

Twenty-four hours after MPP+ treatment, 12 wells of PC12 cells from same treatment group in a 24 -well plate were pooled into one single sample. Two control and two MPP+-treated samples were prepared for microarray hybridization. Total RNA was extracted using Qiagen ${ }^{\mathrm{TM}}$ RNeasy Mini Kits (Qiagen, Valencia, CA) following the RNeasy mini protocols for isolation from animal cells (I. spin protocol). RNA quantity was measured using the NanoDrop ${ }^{\circledast}$ ND-1000 UV-Vis Spectrophotometer (Wilmington, DE), while RNA quality was monitored using Agilent 2100 bioanalyzer and expressed as RNA integrity number (RIN) value using Agilent 2100 RIN Beta Version Software (Palo Alto, CA). For all 4 RNA samples, the ratios of 260/280 (indication of protein contamination) and 260/230 (indication of reagent contamination) determined by the NanoDrop spectrophotometer were above 2 , and the RIN values determined by an Agilent bioanalyzer were 10 (Best RNA quality according to the grading of Agilent 2100 RIN Software). 


\section{Microarray studies}

Agilent 22K 60-mer oligonucleotide microarray slides (Palo Alto, CA) were used and a dye-swap experimental design was applied. High-quality RNA samples (200 ng each) acquired from PC12 cells were amplified and labeled with Cy5-and Cy3-CTP (Amersham Biosciences) to produce labeled cRNA using Agilent low RNA input fluorescent linear amplification kits following the manufacturers protocol. After the amplification and labeling, the dye-incorporation ratio was determined using a Nanodrop spectrophotometer and the ratios were within 10 to 20 pmol per $\mu \mathrm{g}$ cRNA, the range the manufacturer suggests prior to hybridization. For hybridization, the Agilent 60-mer oligo microarray processing protocol (Rev. 7, SSC Wash/6-screw hybridization chamber) was strictly followed. Briefly, 750 ng Cy3-labeled control and 750 ng Cy5-labeled $\mathrm{MPP}^{+}$-treated sample were mixed and incubated with an Agilent microarray slide for 17 hours using an Agilent in situ hybridization kit following SSC buffer washing. Sample pairs were dye-swapped and processed at the same time. The washed slides were immediately dried using an ultra pure filtered $\mathrm{N}_{2}$ stream in an ozonefree Biobubble. After drying, the slides were scanned using an Axon GenePix 4000B scanner with the PMT settings at 770 for Cy5 and 670 for Cy3, and the raw data were generated using GenePix Pro 6.0 software (Axon Instruments, Union City, CA).

\section{Data analysis and MOT interpretation}

Four datasets were acquired in this experiment, Slide 230: control 1 (Cy3)/treated 1(Cy5); Slide 231: control 2(Cy3)/treated 2(Cy5); Slide 232 (dye-swap of slide 230): control 1 (Cy5)/treated 1 (Cy3); Slide 233 (dye-swap of slide 231): control 2(Cy5)/treated 2(Cy3). Raw data generated from GenePix Pro 6.0 software was input into the ArrayTrack database. ArrayTrack is logically constructed of three linked components: a) a database (MicroarrayDB) that stores microarray experiment information; b) tools (TOOL) for data visualization and analysis; and c) libraries (LIB) that provide curated functional data from public databases for data interpretation. Specifically, ArrayTrack is MIAME (Minimum Information About A Microarray Experiment) supportive for storing both microarray data and experiment parameters associated with a toxicogenomics study. A quality control mechanism is implemented to assess the quality of entire expression data as well as quality of each spot on the chip. In addition, many data analysis and visualization tools are available with ArrayTrack, including four normalization methods, several statistical approaches for identification of differentially expressed genes, clustering/classification methods. ArrayTrack also provides a rich collection of functional information about genes, proteins and pathways drawn from various public biological databases for facilitating data interpretation $[10,46]$. After data input, an auto- mated data quality control was made by serial criteria of data quality control parameters in ArrayTrack to assure the data quality (Fig. 1A). Subsequently, data were normalized using the Lowess normalization method [47] to correct intensity-dependent ratio bias in ArrayTrack (Fig. 1B). Raw intensity data were logarithm (base 2) transformed and the log ratio of treated/control was calculated in ArrayTrack. The data set was then exported and the subsequent data analysis was performed employing JMP statistical software 5.0.1 and Spotfire Decisionsite bioinformatics software. The genes were categorized based on their functions derived from OMIM http:/ www.ncbi.nlm.nih.gov and PubMed literature http:// www.pubmed.com as well as GO biological process and molecular functions.

\section{IRIDESCENT}

A software package called IRIDESCENT [48-50] was also used to tie responding genes back to the published literature and identify commonalities among and between genes, diseases, chemical compounds, ontological categories and FDA-approved drugs. Commonalities are scored based upon how many genes within the entire set of microarray responders are observed to be related to each "object" via their co-occurrence within MEDLINE abstracts versus how many relationships would be expected statistically, by chance[49]. This enables validation of experimental data by comparing the microarray response to the published literature to verify that at least some previously documented relationships are being reproduced by the experiment. It also enables the identification of common themes and potential new leads. Graphs were drawn using GraphViz, a software package written by AT\&T Labs.

\section{Results}

\section{Microarray data consistency}

Data consistency was examined employing both ArrayTrack tools and JMP software. Figure 2 shows the correlation ratios between sample pairs $(\mathrm{r}=0.898$ for slide 230 versus $231 ; \mathrm{r}=0.922$ for slide 232 versus 233), indicating data consistency between biological samples. However, poor correlation ratios of dye-swapped slides (Slide 230/232 and slides 231/233) were observed in this study (Fig. 3) due to anti-correlation, a common phenomenon in dye-swapped slides. Further analysis using ArrayTrack tools indicated that these spots are consistent in the two swapped-slide sets (shown red) (Fig. 3A) and most of them are low-intensity spots and internal Cy3 controls (shown red) (Fig. 3B).

\section{Identification of genes altered by $\mathrm{MPP}^{+}$treatment}

Genes with the lowest average intensity in this study (an arbitrary threshold at $\log 2$ transformed intensity $=8$ ) were excluded to reduce variance. Log ratios of the dye- 
A ata from file 2004-09-01-231 PMT 770-670.gpr Control PAI 770.670 ( hyb: Slide 231 Control)

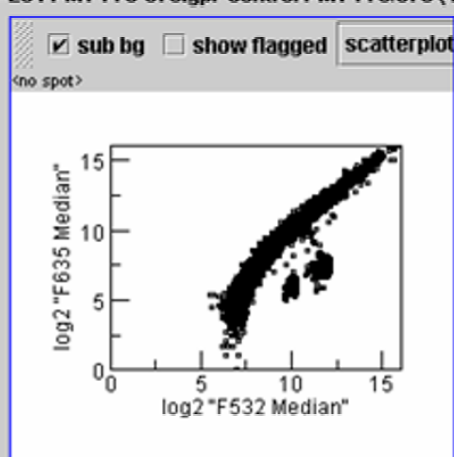

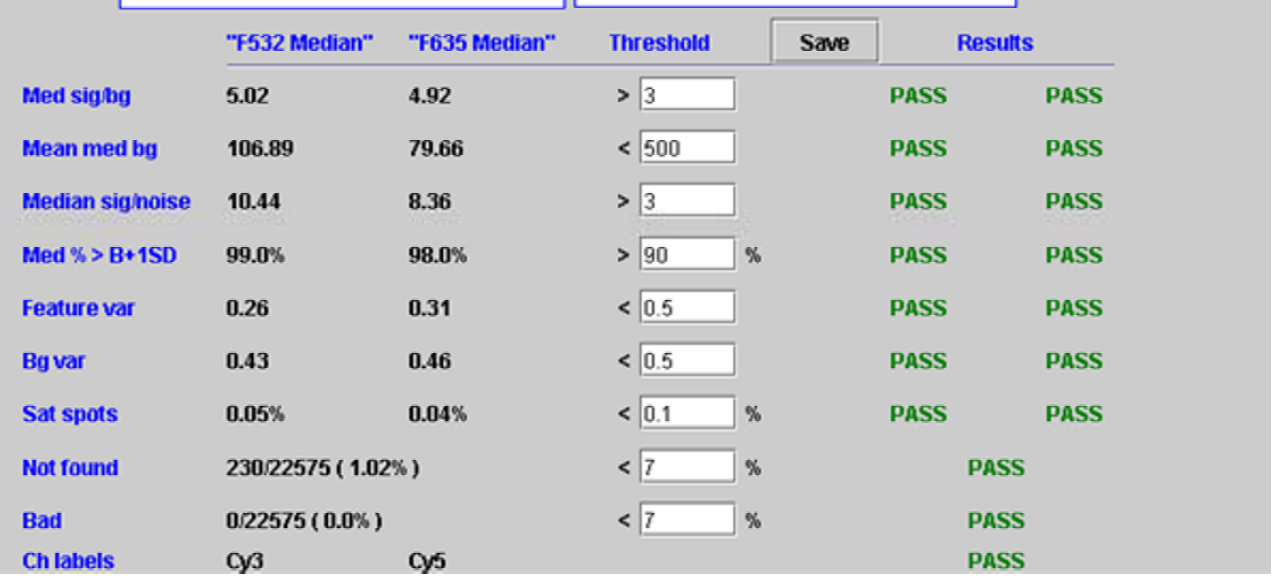

B

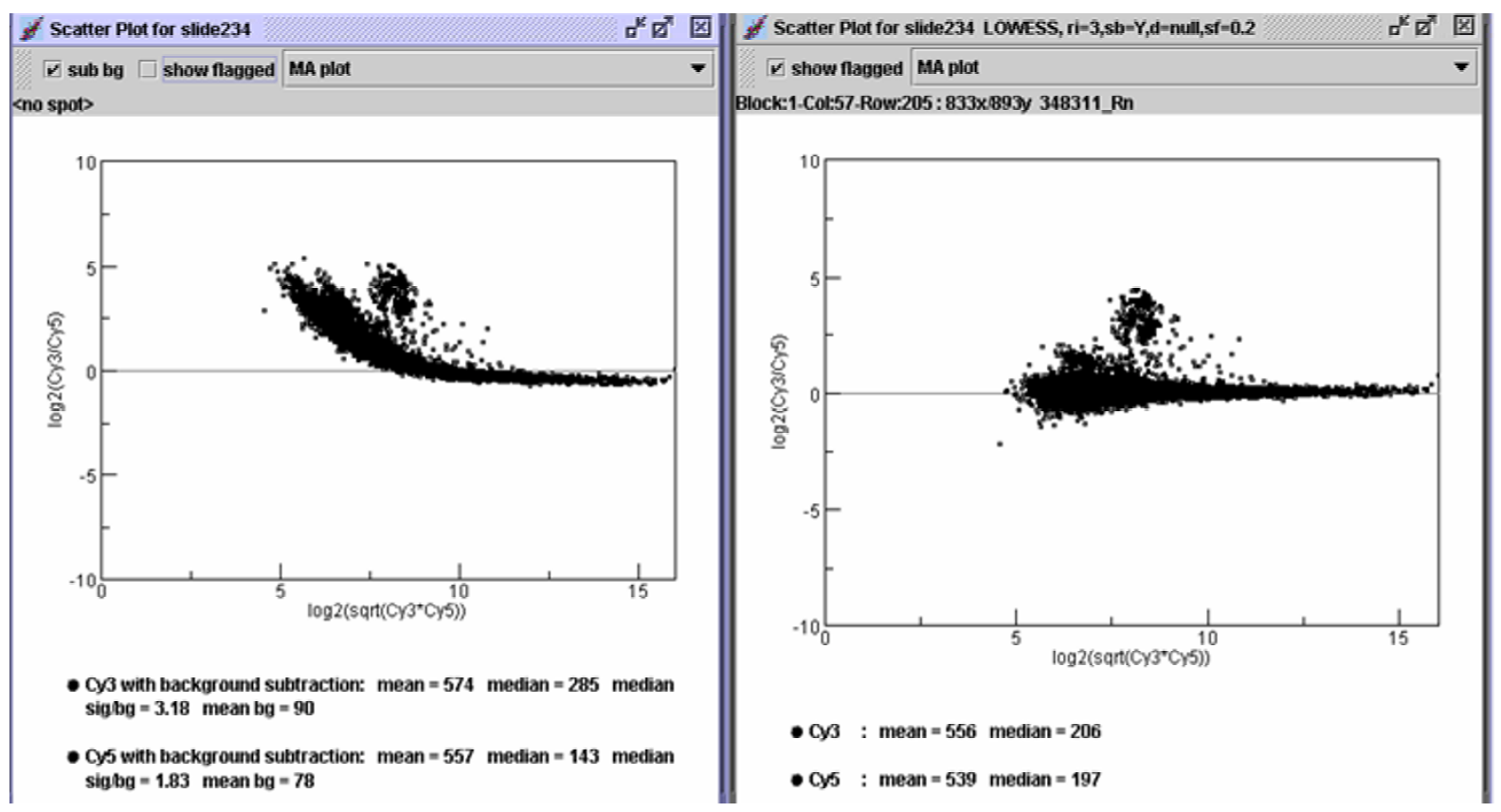

Figure I

Data quality control and Lowess normalization. A. the graph shows a sample of data quality controlled by ArrayTrack. The lower part of Figure IA showed the criterion parameters, the values of Cy3 (F532) and Cy5 (F635), default threshold, and if the specific slide passed the threshold. The upper part shows the scatter plot of the two dyes (Cy3 and Cy5) (Left) and the spot density distribution (right). B. Lowess normalization. The left and right panel shows the MA plot before and after the normalization, respectively. 
A

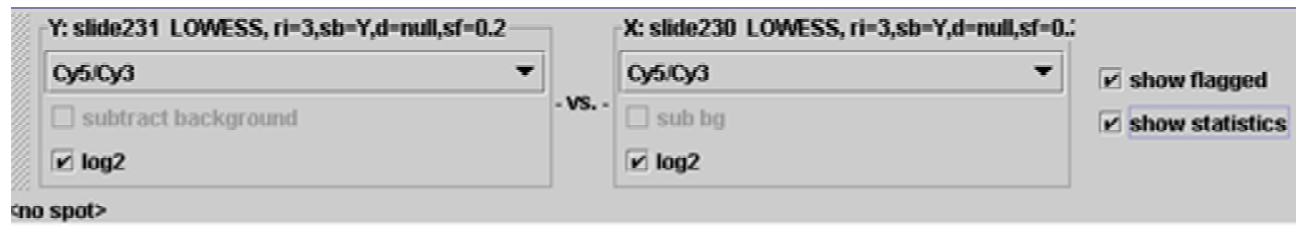



$r=0.898, r^{\wedge} 2=0.806$

B
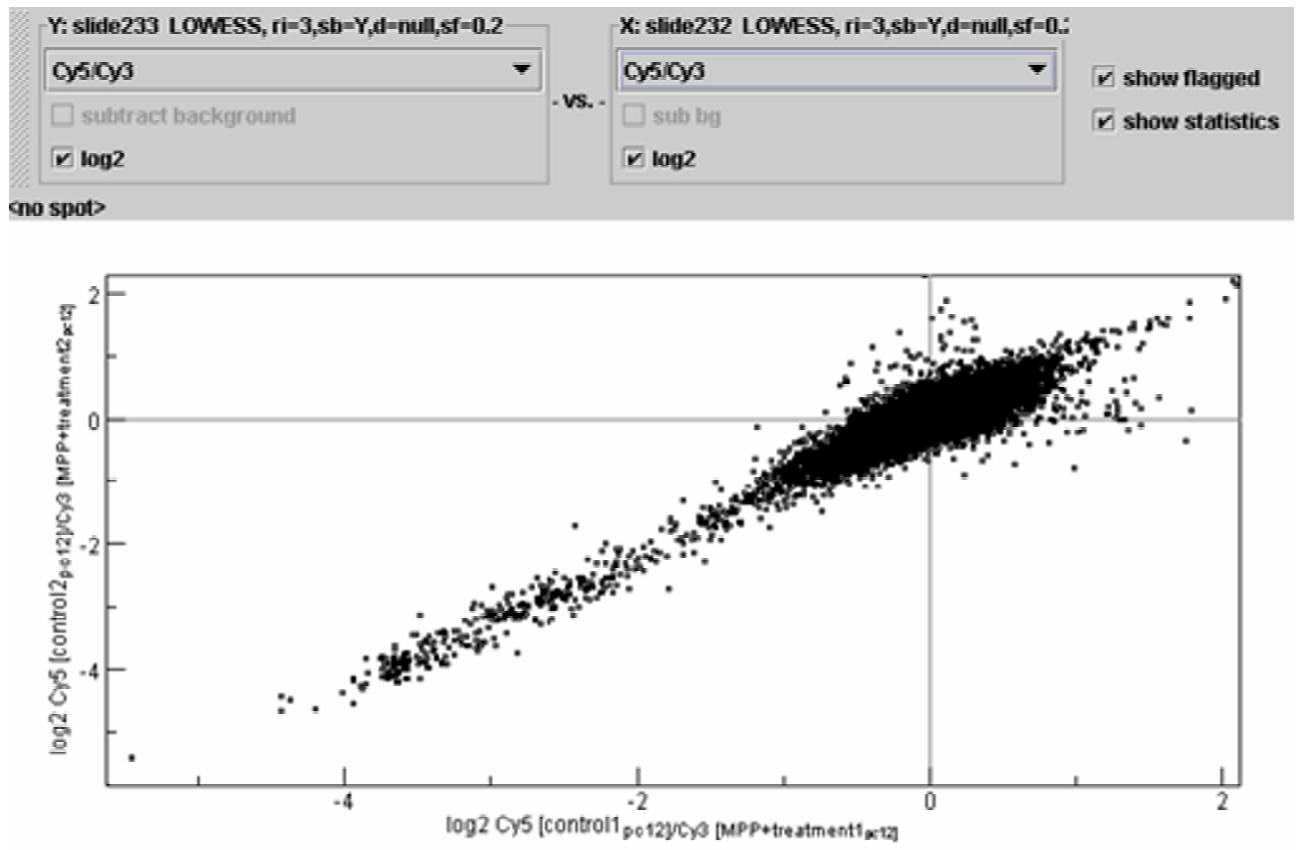

$r=0.922, r^{\wedge} 2=0.849$

Figure 2

Pearson correlation ratio between biological repeats determined by mixed scatter plot tool in ArrayTrack. A. correlation of slide 230 (treated/control sample pair I)/23I (treated/control sample pair 2); B. correlation of slide 232/233. It should be noted that all the Agilent embedded positive and negative controls were included. 
A.

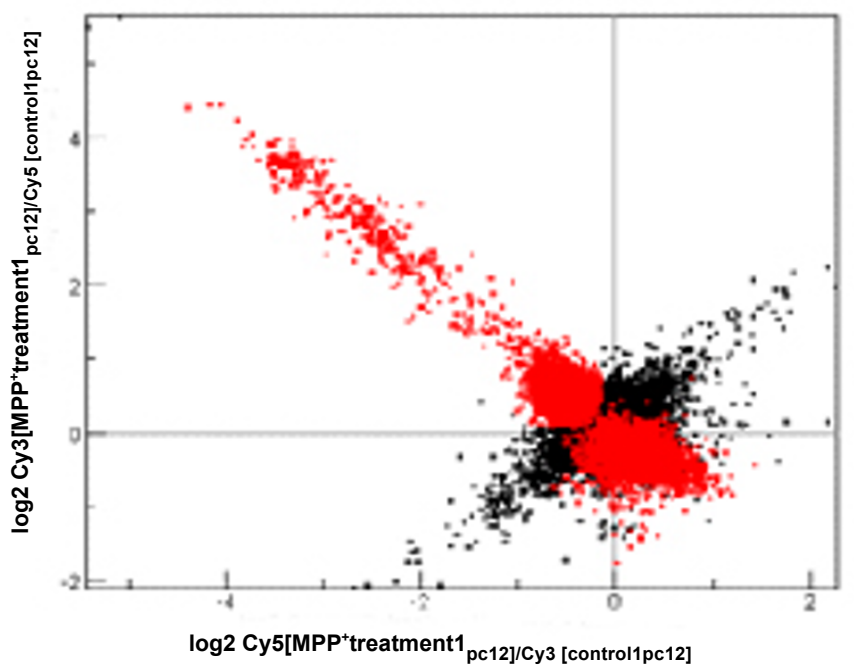

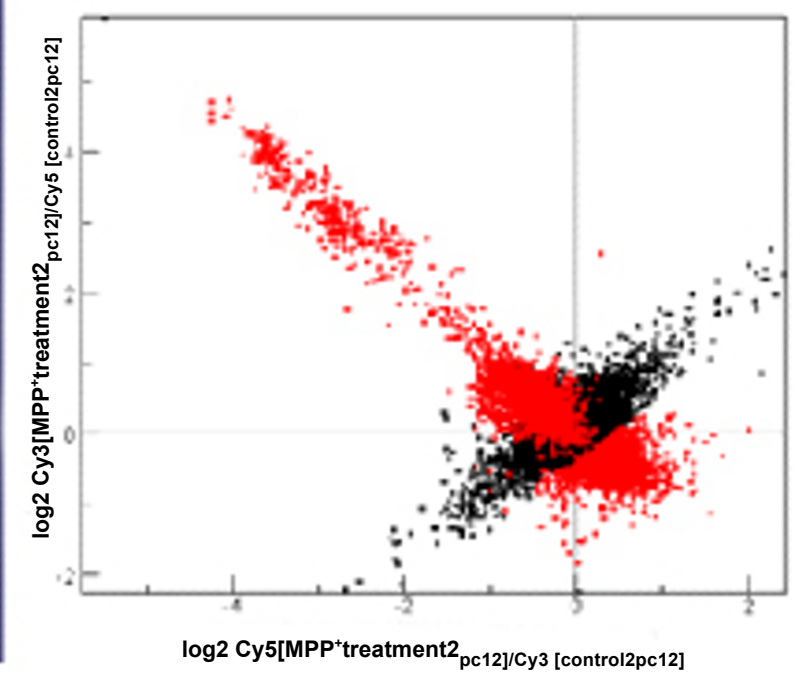

$\log 2$ Cy5[MPP ${ }^{+}$treatment2 ${ }_{\mathrm{pc} 12] / C y 3}$ [control2pc12]
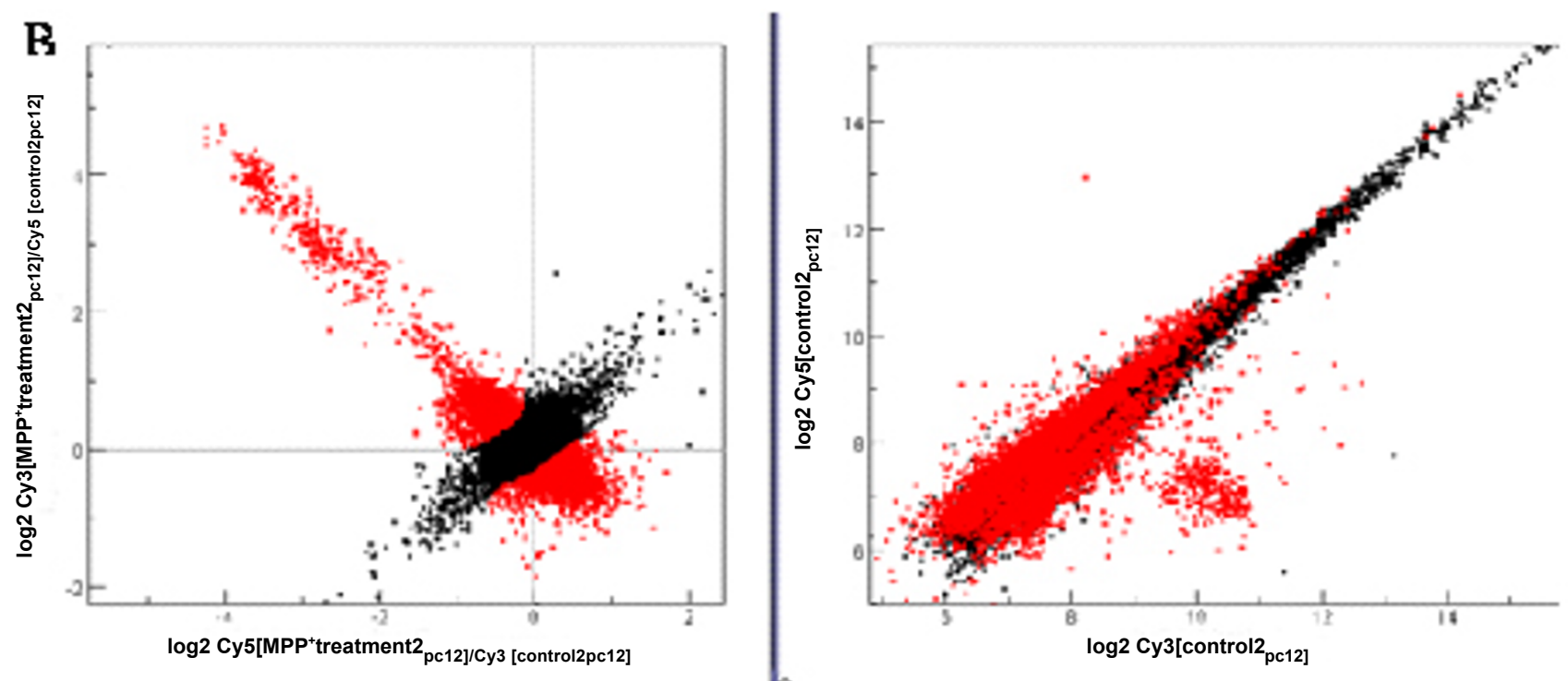

Figure 3

Anti-correlation spots were determined in ArrayTrack. A. Determination of the consistency of anti-related spots in different dye-swapped slide sets. The left panel shows the scatter plot of slide 230/232 and the right shows the scatter plot of slide 23I/ 233. Red color labeled the same spots in the two graphs. B. Determination of the intensity of anti-related spots. The left panel shows the anti-correlation effect of slide $23 \mathrm{I} / 233$ and the right one shows the intensity scatter plot of Cy5 and Cy3 of each spot on slide 23I. Red color labeled represents the anti-correlated spots (left) and their corresponding log intensities (right). It should be noted that slide $23 \mathrm{I}$ is used as an example to show the intensities of anti-correlated spots, but similar results are observed in all other 3 slides. 


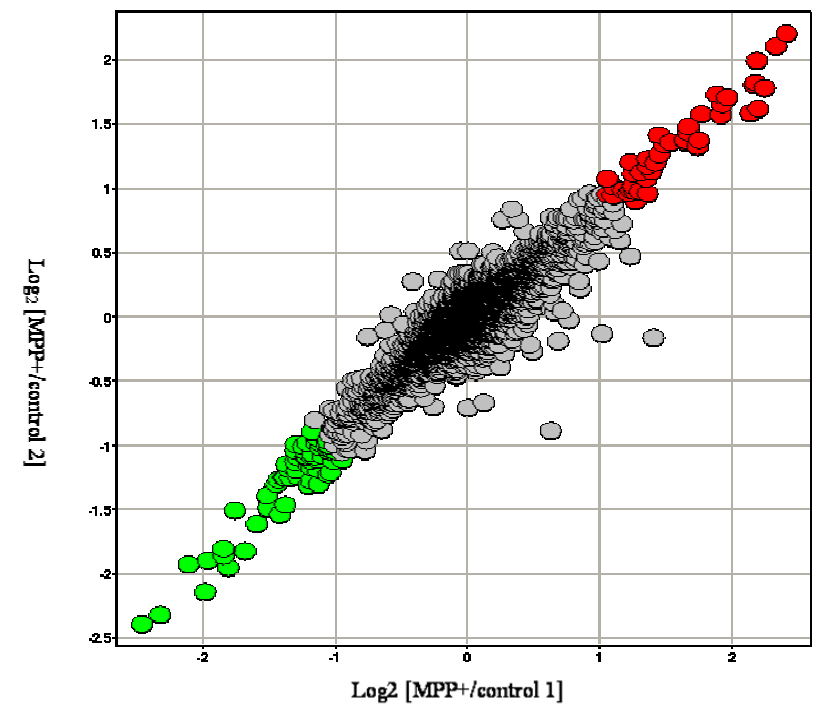

\section{Figure 4}

Scatter plot of the averaged log ratio of dye-swapped slide sets (Avg [230+232] / Avg [23 I+233]) in Spotfire (Correlation ratio: $R=0.90)$. Red labeled spots represents those with log values $\geq$ I (2-fold and above increase) and green labeled spots represents those with log values $\leq-$ I (2-fold and above decrease).

swapped slides were averaged and the mean of two sample pairs were subsequently used to determine the fold change of gene expression in $\mathrm{MPP}^{+}$-treated groups in contrast to control. Figure 4 shows the correlation of the treated/control log (base 2) of the two sample pairs after the dye-swapped slides were averaged $(r=0.90)$, indicating low variance between the two samples sets. In this study, a 2-fold cutoff was applied as significant. Genes with $\log 2$ transformed ratio $\left(\mathrm{MPP}^{+}\right.$treated/control $)=1$ (representing 2-fold and above increase) showed red and $\leq 1$ (representing 2-fold and above decrease) showed green. In total, there were 106 genes (44 genes induced and 62 genes repressed) with equal to and greater than a 2-fold change with $\mathrm{MPP}^{+}$treatment.

\section{MOT analysis}

Based on GO term information, OMIM and PubMed literature, ArrayTrack was used to categorize genes into 6 functional groups, which were: Oxidative stress, DNA and protein damage, metabolic process, neurotransmission and neuronal growth, cell arrest and apoptosis, and cell cycle (Tables 1, 2, 3, 4, 5, 6). Additionally, genes that cannot be categorized or with unclear functions were also listed (Table 7).

\section{Genes associated with oxidative stress (Table I)}

Nine genes were functionally categorized in this group. Vmp1 is a stress-induced gene which may promote formation of intracellular vacuoles followed by cell death [51]. Although it is still not clear the exact function of isg12(b), it is believed to play a role in resisting cellular or environmental stress. Herpud 1 encodes an endoplasmic reticulum stress-inducible protein [52]. Heat shock protein is generally induced by oxidative stress. Ephrin A1 acts as an early response protein in response to oxidative stress. This gene along with its receptor increased in response to DNA damage and is regulated by p53 in apoptosis [53]. Ftl1 is a gene that is often induced due to iron-related oxidative stress, which is important for Parkinson's disease [54]. The induction of these genes indicates that $\mathrm{MPP}^{+}$may induce oxidative stress in PC12 cells. However, leukotriene B4 12-hydroxydehydrogenase which also plays a role in antioxidative function [55], CD24 involved in defense response [56] and Gstm1, a general stressresponse gene, were down-regulated in response to $\mathrm{MPP}^{+}$ treatment, an outcome in opposition to the enhanced oxidative stress hypothesis. However, it should be noted that the above 3 genes are also involved in other functions. Alterations of these 3 genes may provide other mechanistic information for MPP+-induced toxicity.

\section{Genes associated with DNA and protein damage (Table 2)} Both Myd116 [57] and Ddit3 (OMIM: +126337) are DNA-damage inducible genes, and their induction provides direct evidence for DNA damage with $\mathrm{MPP}^{+}$treatment. Dut is involved in purine metabolism, thus, the decrease of this enzyme may compromise the DNA-repair system. In addition, as mentioned above, increased expression of ephrin A1 is also an indication of DNA damage. Limited evidence was found to indicate protein damage. Tryptophanyl-tRNA synthetase catalyzes the first step of protein synthesis and is an essential function in the cell's protein synthesis machinery (OMIM: *191050). Cathepsin $\mathrm{L}$ is a protein associated with proteolysis and peptidolysis and induced by oxidative stress $[58,59]$. These genes, along with heat shock protein 70 , indicate cellular response to protein damage. Tcp1 functions as a cytosolic chaperone in the biosynthesis of tubulin $[60,61]$. Although there is no evidence to indicate that this protein is involved in protein damage and repair, it has been reported that tubulin is involved in $\mathrm{MPP}^{+}$elicited toxicity in PC12 cells [62]. The decreased expression of this gene may affect the synthesis of tubulin, whose assembly into microtubules is critical to many cellular processes. It should be noted that LOC296368 has a sequence similar to ubiquitin-conjugation enzyme E2C, and is down-regulated with $\mathrm{MPP}^{+}$treatment. However, because the exact function of this sequence is still unknown, the effect of these data on our hypothesis is unclear. 
Table I: Genes associated with oxidative stress

\begin{tabular}{|c|c|c|c|c|}
\hline UniGene ID & Genbank Acc ID & Gene Symbol & Gene Name & Fold change \\
\hline Rn.840 & NM_138839 & Vmpl & vacuole Membrane Protein I & 3.18 \\
\hline Rn. 10656 & NM_I 138863 & Ltb4dh & leukotriene B4 I2-hydroxydehydrogenase & -4.99 \\
\hline Rn.22509 & BF398773 & isg 12 (b) & putative ISG I 2(b) protein & 3.76 \\
\hline Rn.II088 & NM_0I3083 & Hspa5 & heat shock $70 \mathrm{kD}$ protein 5 & 4.03 \\
\hline Rn.4028 & NM_053523 & Herpud I & $\begin{array}{l}\text { homocysteine-inducible, endoplasmic reticulum stress-inducible, } \\
\text { ubiquitin-like domain member I }\end{array}$ & 2.56 \\
\hline Rn.93760 & NM_0I70I4 & Gstm I & glutathione S-transferase, mu I & -2.60 \\
\hline Rn. 1905 & NM_022500 & Ftll & ferritin light chain I & 2.85 \\
\hline Rn.8427 & BF284II20 & Efnal & ephrin AI & 2.03 \\
\hline Rn.6007 & NM_0I 2752 & $\mathrm{Cd} 24$ & CD24 antigen & -3.80 \\
\hline
\end{tabular}

Table 2: Genes associated with DNA and protein damage

\begin{tabular}{|c|c|c|c|c|}
\hline UniGene ID & Genbank Acc & Gene Symbol & Gene Name & Fold change \\
\hline Rn.2232 & NM_I33546 & MydII6 & myeloid differentiation primary response gene 116 & 3.50 \\
\hline Rn.6102 & NM_053592 & Dut & Deoxyuridinetriphosphatase (dUTPase) & -2.46 \\
\hline Rn.III83 & NM_024I34 & Ddit3 & DNA-damage inducible transcript 3 & 3.57 \\
\hline Rn.I4939 & $\mathrm{B} 1286828$ & Wars & tryptophanyl-tRNA synthetase & 2.12 \\
\hline Rn.7102 & $\mathrm{A} 1412322$ & Tcpl & $\mathrm{t}$-complex protein I & -2.06 \\
\hline Rn.3102 & All 02920 & LOC296368 & $\begin{array}{l}\text { similar to ubiquitin-conjugating enzyme E2C; DNA segment, Chr } 2 \text {, } \\
\text { ERATO Doi } 695 \text {, expressed }\end{array}$ & -2.04 \\
\hline Rn.II088 & NM_0I3083 & Hspa5 & heat shock $70 \mathrm{kD}$ protein 5 & 4.03 \\
\hline Rn. 1294 & NM_013156 & Ctsl & cathepsin L & 2.89 \\
\hline
\end{tabular}

Table 3: Genes associated with metabolic process

\begin{tabular}{|c|c|c|c|c|}
\hline UniGene ID & Genbank Acc & Gene Symbol & Gene Name & Fold change \\
\hline Rn. 10826 & NM_030834 & Slcl6a3 & monocarboxylate transporter & -2.18 \\
\hline Rn.83595 & NM_03184I & Scd2 & stearoyl-Coenzyme A desaturase 2 & -2.20 \\
\hline Rn.874 & NM_0I2615 & Odcl & ornithine decarboxylase I & -2.22 \\
\hline Rn.29938 & $\mathrm{Al} 409214$ & LOC360688 & $\begin{array}{l}\text { similar to glucan (I,4-alpha-), branching enzyme I; DNA segment, } \\
\text { Chr 16, ERATO Doi 536, expressed }\end{array}$ & -5.38 \\
\hline Rn.37838 & NM_022922 & LOC300465 & similar to triosephosphate isomerase I & -2.83 \\
\hline Rn.3687 & NM_0I7025 & Ldha & lactate dehydrogenase $\mathrm{A}$ & -3.54 \\
\hline Rn.64496 & NM_023964 & Gapds & glyceraldehyde-3-phosphate dehydrogenase, spermatogenic & -2.18 \\
\hline Rn.28161 & NM_053445 & Fads I & fatty acid desaturase I & -2.28 \\
\hline Rn.41024 & NM_021655 & Chga & chromogranin A & -2.07 \\
\hline Rn.8782I & NM_053623 & Acsl4 & acyl-CoA synthetase long-chain family member 4 & 2.15 \\
\hline Rn.8782I & NM_053623 & Acsl4 & acyl-CoA synthetase long-chain family member 4 & 2.84 \\
\hline
\end{tabular}

\section{Genes associated with metabolic processes (Table 3)}

If cellular functions are severely damaged, it is expected that most metabolic activities, especially fuel-utilization and energy metabolism, will be compromised. As Table 3 shows, MPP+ induces suppression of chromogranin A, a gene that modulates glucose, lipid and protein metabolism, and other genes associated with energy production, except acsl4. Therefore, we can primarily conclude that metabolic processes were down-regulated by $\mathrm{MPP}^{+}$in PC12 cells. In addition, chromogranin A is also co-stored and co-released with catecholamines from storage granules in the adrenal medulla (OMIM: *118910). Although the function is still not known, the decrease of chromogranin A may indicate decreased dopamine content with $\mathrm{MPP}^{+}$treatment as previously reported [33,37].

\section{Genes associated with neurotransmission and neuronal growth (Table 4)}

$\mathrm{MPP}^{+-i n d u c e s}$ dopamine depletion, however, our preliminary study using real-time PCR has demonstrated that there are only minor gene expression changes with $\mathrm{MPP}^{+}$ treatment in PC12 cells (data not shown), unlike that in vivo [28]. In this study, instead of tyrosine hydroxylase, dopa decarboxylase (Ddc) was down-regulated following 
Table 4: Genes associated with neurotransmission and neuronal growth

\begin{tabular}{llll}
\hline UniGene ID & Genbank Acc ID & Gene Symbol & Gene Name \\
\hline Rn.9704 & NM_030997 & Vgf & VGF nerve growth factor inducible \\
Rn.I2I00 & NM_03I82I & Plk2 & polo-like kinase 2 (Drosophila) \\
Rn.5785 & NM_05360I & Nnat & neuronatin \\
Rn.I4673 & BI30256I & LOC30360I & similar to Cytochrome b56I (Cytochrome b-56I) \\
Rn.I4673 & BI30256I & LOC30360I & similar to Cytochrome b56I (Cytochrome b-56I) \\
Rn.2874 & NM_0I7I87 & Hmgb2 & high mobility group box 2 \\
Rn.II064 & NM_0I2545 & Ddc & dopa decarboxylase \\
Rn.II064 & NM_0I2545 & Ddc & dopa decarboxylase \\
Rn.10784 & NM_I33303 & Bhlhb3 & basic helix-loop-helix domain containing, class B3 \\
\hline
\end{tabular}

Table 5: Genes associated with cell growth arrest and apoptosis

\begin{tabular}{lllll}
\hline UniGene ID & Genbank Acc ID & Gene Symbol & Gene Name & Fold change \\
\hline Rn.22325 & NM_I44755 & Trib3 & tribbles homolog 3 (Drosophila) & 4.66 \\
Rn.14733 & BI303289 & Gas5 & growth arrest specific 5 & 2.47 \\
Rn.10250 & NM_024I27 & Gadd45a & growth arrest and DNA-damage-inducible 45 alpha & 2.19 \\
Rn.8427 & BF284I20 & Efnal & ephrin AI & 2.03 \\
Rn.840 & NM_138839 & VmpI & vacuole Membrane Protein I & 3.18 \\
Rn.III80 & NM_053294 & Adora2a & adenosine A2a receptor & -2.31 \\
Rn.10232 & NM_0I27I5 & Adm & adrenomedullin & -2.13 \\
\end{tabular}

$\mathrm{MPP}+$ treatment. In addition, cytochrome b561, a major transmembrane protein that is specific to catecholamine and neuropeptide secretory vesicles of the adrenal medulla (OMIM: *600019), was down-regulated. As mentioned above, chromogranin A may be involved in dopamine metabolism in PC12 cells.

In PC12 cells, genes involved in neurogenesis and neuronal development were down-regulated following $\mathrm{MPP}^{+}$ treatment. These include Vgf (OMIM: *602186), Nnat [63], Plk2 [64], Hmgb2 (GO terms, biological process) and Bhlhb3 (GO terms, biological process). The decrease of these growth-related genes may suggest cell damage, cell growth arrest and a tendency toward apoptosis.

\section{Genes associated with general cell growth arrest and apoptosis (Table 5)}

With $\mathrm{MPP}^{+}$treatment, the expression of Gadd45a and Gas5 [65], genes associated with cell growth and responsive to DNA-damage stimulus [66], were induced. As shown above, induction of ephrin A1 also indicates p53dependent activation in response to DNA damage [53]. Furthermore, Trib3 (Kegg pathway) and Vmp1, which are involved in apoptosis, are both induced. Adenosine A2a receptor is also included in this group because it has been reported that Activation of $\mathrm{A} 2 \mathrm{~A}$ adenosine receptors (Adora2a) was found to prevent reactive oxygen species (ROS) formation and apoptosis in pheochromocytoma PC12 cells [67]. The repression of this gene may facilitate apoptosis and ROS damage. In addition, this receptor is cAMP mediated, thus the repression of this receptor may be involved in subsequent cAMP regulated functions, such as CREB. ADM is one of the proteins that are CAMP pathway regulated. Although the function is still not clear, it has been reported to be highly expressed in pheochromocytoma and adrenal medulla (OMIM: *103275).

\section{Genes associated with cell-cycle (Table 6)}

It is evident that if cell growth is arrested, cell cycle and proliferation should be ceased. Thus, it is not surprising to see that genes for anti-proliferation (Btg1, Copeb) were induced and genes for cell cycle and replications were reduced. As shown in Table 6, Mcmd6 (mini chromosome maintenance deficient 6 ), which belongs to a family of early S-phase proteins required for DNA replication, may play a role in cell-cycle progression and DNA replication [68]. Calcyclin (S100A6) is a calcium-binding protein that belongs to the family of S100 proteins. Its gene was discovered on the basis of its cell cycle-dependent expression. This gene is expressed at its maximal level during the transition between $G_{0}$ to $S$ phase of the cell cycle $[69,70]$. Snf1lk encodes a protein kinase that may function in cell cycle regulation [71]. Tcf19 is a transcription factor that may be involved in cell growth [72]. H2Afz is a protein synthesized throughout the cell cycle (OMIM: *142763). These genes, along with some typical genes of the cell cycle (cdc2a, S-phase kinase-associated protein, Rfc2, Ret, Pcna), were all down-regulated by $\mathrm{MPP}^{+}$treatment. Although the oncogene c-Myc has been considered a gene for proliferation, it is usually up-regulated during apoptosis $[73,74]$. Thus, the induction of this gene is consistent with apoptotic processes induced by MPP+. 
Table 6: Genes associated with cell-cycle

\begin{tabular}{|c|c|c|c|c|}
\hline UniGene ID & Genbank Acc ID & Gene Symbol & Gene Name & Fold change \\
\hline Rn. 14867 & All 03327 & Tcfl9 & transcription factor 19 & -2.19 \\
\hline Rn.42905 & NM_021693 & Snfllk & SNFI-like kinase & -2.05 \\
\hline Rn.3233 & NM_053485 & S100a6 & SI00 calcium binding protein A6 (calcyclin) & -2.09 \\
\hline Rn.22905 & AA899195 & $\operatorname{Rfc2}$ & replication factor C (activator I) 2 (40 kD) & -2.14 \\
\hline Rn.22905 & AA899195 & $\operatorname{Rfc} 2$ & replication factor C (activator I) 2 (40 kD) & -2.14 \\
\hline Rn.44I78 & A)299016 & Ret & ret proto-oncogene & -3.61 \\
\hline Rn.223 & NM_02238I & Pcna & proliferating cell nuclear antigen & -2.41 \\
\hline Rn. 12072 & NM_0I2603 & Мyс & v-myc avian myelocytomatosis viral oncogene homolog & 2.02 \\
\hline Rn.33226 & UI7565 & Mcmd6 & mini chromosome maintenance deficient 6 (S. cerevisiae) & -2.54 \\
\hline Rn.4l428 & Al706769 & LOC30495I & similar to NUF2R protein & -2.10 \\
\hline Rn.8884 & All I 2987 & LOC29207I & similar to CDTI protein & -2.26 \\
\hline Rn.3477 & AA858962 & LOC287280 & $\begin{array}{l}\text { similar to S-phase kinase-associated protein IA isoform b; organ of } \\
\text { Corti protein 2; transcription elongation factor B (SIII), polypeptide } \\
\text { I-like; RNA polymerase II elongation factor-like protein OCP2; cyclin } \\
\text { A/CDK2-associated pI9 }\end{array}$ & -2.74 \\
\hline Rn.57 & NM_019904 & Lgals I & lectin, galactose binding, soluble I & -2.18 \\
\hline Rn.3636 & NM_022674 & $\mathrm{H} 2 \mathrm{afz}$ & $\mathrm{H} 2 \mathrm{~A}$ histone family, member $\mathrm{Z}$ & -2.23 \\
\hline Rn.7947 & $\mathrm{B} 1298478$ & Copeb & core promoter element binding protein & 2.01 \\
\hline Rn.II252 & NM_03I642 & Copeb & core promoter element binding protein & 2.08 \\
\hline Rn. II 252 & NM_031642 & Copeb & core promoter element binding protein & 2.72 \\
\hline Rn.6934 & NM_019296 & Cdc2a & cell division cycle 2 homolog A (S. pombe) & -2.50 \\
\hline Rn. 1000 & NM_0I7258 & Btgl & B-cell translocation gene I, anti-proliferative & 2.17 \\
\hline Rn. 1000 & NM_0I7258 & Btgl & B-cell translocation gene I, anti-proliferative & 2.20 \\
\hline
\end{tabular}

Table 7: Genes with unknown functions

\begin{tabular}{|c|c|c|c|c|}
\hline UniGene ID & Genbank Acc & Gene Symbol & Gene Name & Fold change \\
\hline Rn.6738 & AA924324 & LOC305709 & similar to transcription elongation factor IIS - mouse & 2.33 \\
\hline Rn.3494 & NM_019144 & Acp5 & acid phosphatase 5 , tartrate resistant & -3.36 \\
\hline Rn. 13778 & NM_133298 & Gpnmb & glycoprotein (transmembrane) nmb & 2.69 \\
\hline Rn.24007 & AlI78104 & LOC293623 & similar to RIKEN cDNA 2400009B I I gene & -2.10 \\
\hline Rn. 1935 & $\mathrm{~B} 12887 \mathrm{I}$ & LOC305234 & similar to genethonin I & 2.94 \\
\hline Rn.7233 & $\mathrm{Al} 230347$ & Ns5atp9 & Ns5atp9 protein & -4.04 \\
\hline Rn. 18835 & AW252093 & LOC360847 & similar to RIKEN cDNA 2700084 L22 & -2.05 \\
\hline Rn. 12866 & BQ782988 & LOC36II68 & similar to HTPAP protein & 2.32 \\
\hline Rn. 18387 & AW 251335 & LOC 363028 & similar to RIKEN cDNA $2410030 \mathrm{KOI}$ & -2.21 \\
\hline Rn.22267 & AA94398I & LOC3III209 & $\begin{array}{l}\text { similar to endoplasmic reticulum membrane protein with at least } 3 \\
\text { transmembrane domains of bilaterial origin like }(\mathrm{X} 3300)\end{array}$ & -2.05 \\
\hline Rn.8733 & NM_I38892 & LOC300708 & similar to RS2 I-C6 protein & -2.37 \\
\hline
\end{tabular}

\section{Genes with unknown functions (Table 7)}

There are also some genes that cannot be categorized into gene groups. Generally this is due to their unknown functions. However, GPNMB, expressed in melanoma cell lines, was preferentially expressed in low-metastatic cell lines (OMIM: *604368). There was an inverse relationship between the expression of GPNMB compared to calcyclin (OMIM: *604368). In PC12 cells, this pattern was also observed. Acp5 is a gene related to bone growth (OMIM: *171640), which made it difficult to correlate with its function in PC12 cells.

\section{IRIDESCENT Analysis}

Thus far, genes have been discussed individually and in terms of their known ontological processes. Gene categories shown above indicated that $\mathrm{MPP}^{+}$-induced toxicity might be related to the production of oxidative stress, DNA and protein damage, cell growth arrest, cell cycle/ proliferation repression and apoptosis. IRIDESCENT was used to gain a broader perspective on how the 59 responding genes with known functions were related and whether these gene expression changes resonated with MPTPinduced neurotoxicity and Parkinson's disease. Only 47 of these 59 gene names, however, appeared in the literature at least once and could be used in the analysis based on the IRIDESCENT search. Genes with sequence similarity 
to other genes were not used (e.g. the LOC* entries). When examining how each of these genes was related to one another within the scientific literature, 34 genes had no detected relationships, suggesting that at least a few of these genes may be the result of noise or a non-specific response. It is also possible, of course, that their relationship to MPP+ and PD has not yet been documented and are thus valuable leads.

Discarding the genes without known connections, the most apparent pathway identified by the literature analysis was the DNA damage pathway (Figure 5), with GADD45 and GADD153 (Ddit3) in a relatively central role. Interestingly, these genes have been documented in other microarray experiments to play a role in dopamineinduced toxicity [75], yet have been only weakly associated with PD thus far. Both MPTP and PD are included in this graph so that literature relationships to the responding genes are apparent. Note the strong relationship between MPTP and PD and that the genes related to MPTP are also strongly related to PD. Roughly, the graph also segregates between a responding (up-regulated) and repressed (down-regulated) group of genes. Because we expect genes related by function or process in the literature to behave in a similar manner to a greater degree than unrelated genes, this helps confirm the specificity of the microarray experiments conducted. This graph also helps visualize to a greater degree the central players in the transcriptional response - in this case, PCNA, which has been called the "ringmaster of the genome" and can lead to apoptosis when downregulated [76]. GADD45 is also upregulated, which is known to occur after DNA damage [77]. Collectively, these factors within this analysis suggest that the MOT is likely due to DNA damage. As part of the shared relationship analysis, IRIDESCENT also identified Methyl Methanesulfonate (MMS) as being highly related to the responding genes. Because MMS is known to induce DNA damage through DNA alkylation, it would be interesting to compare the MPTP and MMS responses in future microarray experiments to identify both similarities and differences in their gene expression patterns.

\section{Discussion}

During the last decade, DNA microarrays have been one of the hottest topics in biological research and biotechnology industry. The first paper about a DNA microarray was published from Pat Brown's laboratory in Stanford University in 1995 [78]. By the end of 2004, the number of microarray-related publications was 11,625 (http:// www.pubmed.com, keyword searching: DNA microarray). However, data assurance and data quality are still great challenges in microarray studies $[4,79]$. In this study, the experiment was performed under stringent quality control, with minimum standards sets for RNA purity, RNA degradation, and dye-incorporation ratios. The cor-

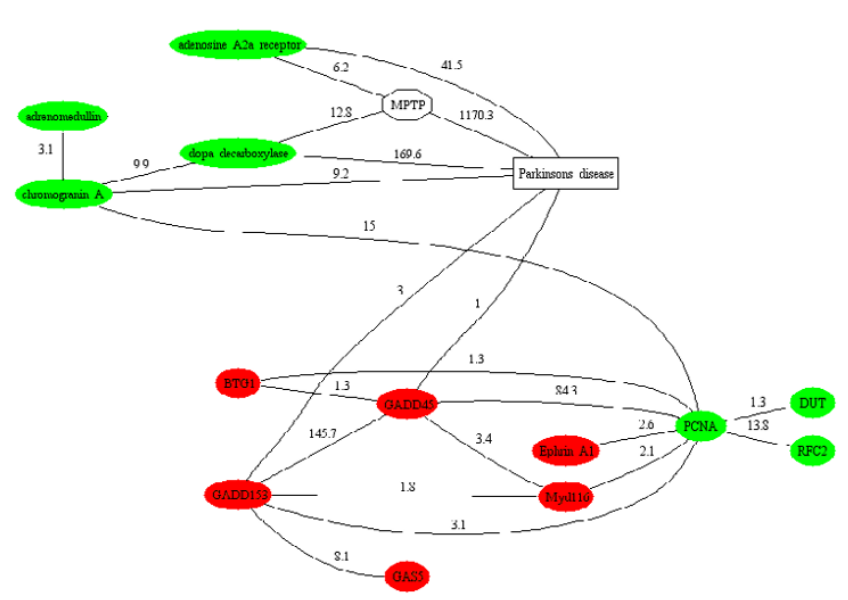

\section{Figure 5}

Within the subset of genes expressed at a 2-fold or greater level in the MPTP microarray experiments, these 13 were found co-mentioned together within MEDLINE abstracts at least twice. Green colors = down-regulated genes, Red = upregulated genes. Relationships with MPTP (octagon) and Parkinson's Disease (rectangle) are also displayed. Relationship weights were calculated as (number of abstract co-mentions $\times 0.5)+($ number of sentence co-mentions $\times 0.8)$.

Relationships with weights $\leq \mathrm{I}$ are not shown.

relation ratio between the two sample-sets was up to 0.9, thus, we assume that variance introduced by the experimental procedure was small. The anti-correlation effect exists more or less in all dye-swapped microarray experiments, which is due to natural differences between the Cy5 and Cy3 dyes. As our data indicated, the anti-correlation was intensity-dependent, and occurred primarily with low-intensity spots. The cut-off threshold applied in this study (log intensity $\geq 8$ ) can, therefore, largely exclude these low intensity spots. This cutoff may cause false-negative discovery because the low-expressed genes, which may be altered by treatment, are also eliminated. However, it was interesting to note that none of the genes with expression levels lower than the cutoff level were changed up to 2-fold with MPP+ treatment. This is mainly due to the dye anti-correlation effect as shown in Figure 2.

In this study, the good correlation of sample set 1 and sample set 2 (Fig. 4) indicated low variance, which made it justifiable to use fold-change criterion to determine genes that were altered following $\mathrm{MPP}^{+}$treatment. Actually, the correlation ratio of the two sample sets was up to 0.98 if only those genes with 2 -fold change were counted (data not shown). Two-fold is a somewhat arbitrary foldchange criterion that has been applied in many microarray studies [80-83], but nonetheless necessary to delineate a tentative set of responders. We have to admit that it is an arbitrary criterion, and it does not mean that the genes altered lower than 2-fold change are not meaning- 
ful. Certainly, more genes will be determined to be significant if the threshold is decreased to 1.5 or lower, but this will produce more false discovery. Currently, this criterion is still the most acceptable criterion regarding the magnitude of fold change and biological significance.

Data interpretation (mechanism of toxicity) is the ultimate and most complicated aspect of a microarray study, in part because there is no standard approach. Although there are more and more tools, websites and biological libraries to assist MOT analysis, biological knowledge and understanding the pertinent literature are generally more important for MOT analysis. Our study indicated that $\mathrm{MPP}^{+}$may produce its toxicity via the production of oxidative stress as indicated by induction of associated genes (Vmp1, Hspa5, Herpud1, Ftl1, Efna1, Ctsl, etc.), and at the same time suppression of general defense systems (Gstm1, Cd24, Adora2a, etc.). Previous studies have demonstrated that $\mathrm{MPP}^{+}$elicits its toxicity in PC12 cells via the production of oxidative stress $[84,85]$, and this study provides evidence of oxidative stress production at the gene level. Oxidative stress may be responsible for the DNA and protein damage as represented by the induction of DNA and protein damage-inducible genes. It has been reported that $\mathrm{MPP}^{+}$elicits DNA damage and subsequent apoptosis [86,87] and induced heat shock proteins such as HSP70, which is an indicator of protein damage and repair $[88,89]$. DNA and protein damage are involved in cell growth arrest and cell cycle repression and eventually apoptosis $[90,91]$. A plethora of evidence has demonstrated that $\mathrm{MPP}^{+}$can elicit cell death in PC12 cells $[34,36,88]$. Therefore, this study confirmed the previous findings at the gene expression level, and more importantly the genes identified in this study suggested specific mechanistic pathways of MPP+-induced toxicity.

In summary, this study provides new insight on the mechanism of toxicity induced by $\mathrm{MPP}^{+}$. Our data indicate that $\mathrm{MPP}+$ induces oxidative stress, elicits damage in DNA and proteins, and causes cell growth arrest, cell cycle suppression and apoptosis. Literature analysis by IRIDESCENT has revealed some genes such as PCNA and GADD45 that are likely central players in this toxic response. In addition, IRIDESCENT analysis demonstrated that some of the genes altered by MPP+ in PC12 cells are involved in MPTP induced neurotoxicity in mice and Parkinson's disease. We have also identified MMS as a compound related to the genes in our experimental transcriptional response, and since no studies on the effects of MMS on PC12 cells have been published thus far, this is a potentially promising avenue for future experimentation the mechanism of toxicity for MPTP.

\section{References}

I. Gershon D: Microarray technology: an array of opportunities. Nature 2002, 4 I 6(6883):885-89I.
2. Lockhart DJ, Barlow C: Expressing what's on your mind: DNA arrays and the brain. Nat Rev Neurosci 200I, 2(I):63-68.

3. Barlow C, Lockhart DJ: DNA arrays and neurobiology - what's new and what's next? Curr Opin Neurobiol 2002, I 2(5):554-56I.

4. Shi L, Tong W, Goodsaid F, Frueh FW, Fang H, Han T, Fuscoe JC, Casciano DA: QA/QC: challenges and pitfalls facing the microarray community and regulatory agencies. Expert Rev Mol Diagn 2004, 4(6):76I-777.

5. Moggs JG, Tinwell H, Spurway T, Chang HS, Pate I, Lim FL, Moore DJ, Soames A, Stuckey R, Currie R, et al.: Phenotypic anchoring of gene expression changes during estrogen-induced uterine growth. Environ Health Perspect 2004, I I 2(16): I589- 1606.

6. Jung JW, Park JS, Hwang JW, Kang KS, Lee YS, Song BS, Lee GJ, Yeo $C D$, Kang JS, Lee WS, et al.: Gene expression analysis of peroxisome proliferators-and phenytoin-induced hepatotoxicity using cDNA microarray. J Vet Med Sci 2004, 66(I I): I329-I 333.

7. Lee GJ, Lee WS, Jeon KS, Um CH, Kim YS, Kim SJ, Lee CH, Yoon HK, Hwang SY, Park JS, et al.: cDNA microarray gene expression analysis and toxicological phenotype for anticancer drug. J Vet Med Sci 2004, 66(I I): I339-1345.

8. Freeman K: Toxicogenomics data: the road to acceptance. Environ Health Perspect 2004, I I 2( I 2):A678-685.

9. Mattes WB, Pettit SD, Sansone SA, Bushel PR, Waters MD: Database development in toxicogenomics: issues and efforts. Environ Health Perspect 2004, I I 2(4):495-505.

10. Tong W, Cao X, Harris S, Sun H, Fang H, Fuscoe J, Harris A, Hong H, Xie Q, Perkins R, et al.: ArrayTrack - supporting toxicogenomic research at the U.S. Food and Drug Administration National Center for Toxicological Research. Environ Health Perspect 2003, III(15):1819-1826.

II. Luyendyk JP, Mattes WB, Burgoon LD, Zacharewski TR, Maddox JF, Cosma GN, Ganey PE, Roth RA: Gene expression analysis points to hemostasis in livers of rats cotreated with lipopolysaccharide and ranitidine. Toxicol Sci 2004, 80(I):203-2 I3.

12. Lutz W, Kur B: [Toxicogenomics. New perspectives for the molecular toxicology]. Med $\operatorname{Pr} 2004$, 55(2): 193-202.

13. Waters MD, Fostel JM: Toxicogenomics and systems toxicology: aims and prospects. Nat Rev Genet 2004, 5( I 2):936-948.

14. Burns RS, Chiueh CC, Markey SP, Ebert MH, Jacobowitz DM, Kopin $\mathrm{IJ}$ : A primate model of parkinsonism: selective destruction of dopaminergic neurons in the pars compacta of the substantia nigra by $\mathrm{N}$-methyl-4-phenyl-I,2,3,6-tetrahydropyridine. Proc Natl Acad Sci U S A 1983, 80(14):4546-4550.

15. Heikkila RE, Hess A, Duvoisin RC: Dopaminergic neurotoxicity of I-methyl-4-phenyl-1,2,5,6-tetrahydropyridine in mice. Science 1984, 224(4656): | $455 \mid-1453$.

16. Agid Y: Parkinson's disease: pathophysiology. Lancet 1991, 337:1321-1324.

17. Dauer W, Kholodilov N, Vila M, Trillat AC, Goodchild R, Larsen KE, Staal R, Tieu K, Schmitz Y, Yuan CA, et al.: Resistance of alphasynuclein null mice to the parkinsonian neurotoxin MPTP. Proc Natl Acad Sci U S A 2002, 99(22): I 4524-I 4529.

18. Speciale S: MPTP: insights into parkinsonian neurodegeneration. Neurotoxicol Teratol 2002, 24(5):607-620.

19. Krieglstein K, Suter-Crazzolara C, Unsicker K: Development of mesencephalic dopaminergic neurons and the transforming growth factor- $\beta$ superfamily. J Neural Transm Suppl 1995, 46:209-216.

20. Kuhn K, Wellen J, Link N, Maskri L, Lubbert H, Stichel CC: The mouse MPTP model: gene expression changes in dopaminergic neurons. Eur J Neurosci 2003, I7(I):I-I2.

21. Przedborski S, Jackson-Lewis V: Mechanisms of MPTP toxicity. Mov Disord 1998, I 3(I):35-38.

22. Markey SP, Johannessen JN, Chiueh CC, Burns RS, Herkenham MA: Intraneuronal generation of a pyridinium metabolite may cause drug-induced parkinsonism. Nature 1984, 3 I I (5985):464-467.

23. Chiba K, Trevor A, Castagnoli NJ: Metabolism of the neurotoxic tertiary amine, MPTP, by brain monoamine oxidase. Biochem Biophys Res Commun 1984, I 20(2):574-578.

24. Davis GC, Williams AC, Markey SP, Ebert MH, Caine ED, Reichert CM, Kopin IJ: Chronic Parkinsonism secondary to intravenous injection of meperidine analogues. Psychiatry Res 1979, I(3):249-254. 
25. Tipton KF, Singer TP: Advances in our understanding of the mechanisms of the neurotoxicity of MPTP and related compounds [Review]. J Neurochem 1993, 6I(4): II91-1206.

26. Ali SF, David SN, Newport GD, L C], Slikker WJ: MPTP-induced oxidative stress and neurotoxicity are age-dependent: evidence from measures of reactive oxygen species and striatal dopamine levels. Synapse 1994, I 8(1):27-34.

27. Ali SF, David SN, Newport G: Age-related susceptibility to MPTP-induced neurotoxicity in mice. Neurotoxicology 1993, I 4(I):29-34

28. Xu Z, Cawthon D, McCastlain KA, Slikker W Jr, Ali SF: Selective alterations of gene expression in mice induced by MPTP. Synapse 2005, 55(I):45-5I.

29. Greene LA, Tischler AS: Establishment of a noradrenergic clonal line of rat adrenal pheochromocytoma cells which respond to nerve growth factor. Proc Nat Acad Sci 1976, 73:2424-2428.

30. Tuler SM, Hazen AA, Bowen JM: Release and metabolism of dopamine in a clonal line of pheochromocytoma (PCI2) cells exposed to fenthion. Fundam Appl Toxicol 1989, I3:484-492.

31. Hatanaka $\mathrm{H}$ : Nerve growth factor-mediated stimulation of tyrosine hydroxylase activity in a clonal rat pheochromocytoma cell line. Brain Res 198I, 222(2):225-233.

32. Rebois RV, Reynolds EE, Toll L, Howard BD: Storage of dopamine and acetylcholine in granules of PCI2, a clonal pheochromocytoma cell line. Biochemistry 1980, 19(6): 1240-1248.

33. Itano $Y$, Kitamura $Y$, Nomura $Y$ : Biphasic effects of MPP+, a possible parkinsonism inducer, on dopamine content and tyrosine hydroxylase mRNA expression in PCI 2 cells. Neurochem Int 1995, 26(2): |65-|7|.

34. Sheng GQ, Zhang JR, Pu XP, Ma J, Li CL: Protective effect of verbascoside on I-methyl-4-phenylpyridinium ion-induced neurotoxicity in PCI 2 cells. Eur J Pharmacol 2002, 45 I (2): I I 9-I 24.

35. Fonck C, Baudry M: Toxic effects of MPP(+) and MPTP in PCI2 cells independent of reactive oxygen species formation. Brain Res 200I, 905(I-2): 199-206.

36. Hartley A, Stone JM, Heron C, Cooper JM, Schapira AH: Complex I inhibitors induce dose-dependent apoptosis in $\mathrm{PCI} 2$ cells: relevance to Parkinson's disease. I Neurochem 1994 63(5): 1987-1990.

37. Xu Z, Cawthon D, McCastlain KA, Duhart HM, D NG, Fang H, Patterson TA, Slikker W], Ali S: Selective alterations of transcription factors in MPP+-induced neurotoxicity in PCI 2 cells. Nuerotoxicology 2005 in press.

38. Chalmers-Redman RM, Fraser AD, Carlile GW, Pong A, Tatton WG: Glucose protection from MPP+-induced apoptosis depends on mitochondrial membrane potential and ATP synthase. Biochem Biophys Res Commun 1999, 257(2):440-447.

39. Freyaldenhoven TE, Ali SF, Hart RW: MPTP-and MPP(+)-induced effects on body temperature exhibit age-and strain-dependence in mice. Brain Res 1995, 688(I-2): $16|-| 70$

40. Lee $\mathrm{CH}$, Han JH, Jang YY, Song JH, Han ES: Differential effect of catecholamines and $\mathrm{MPP}^{+}$on membrane permeability in brain mitochondria and cell viability in PCI 2 cells. Neurochem Int 2002, 40:36I-369.

4I. Ryu EJ, Harding HP, Angelastro JM, Vitolo OV, Ron D, Greene LA Endoplasmic reticulum stress and the unfolded protein response in cellular models of Parkinson's disease. I Neurosci 2002, 22(24): 10690-10698.

42. Salinas M, Martin D, Alvarez A, Cuadrado A: Akt I/PKBalpha protects $\mathrm{PCI} 2$ cells against the parkinsonism-inducing neurotoxin I-methyl-4-phenylpyridinium and reduces the levels of oxygen-free radicals. Mol Cell Neurosci 200I, I7(I):67-77.

43. Ribeiro L, Azevedo I, Martel F: Comparison of the effect of cyclic AMP on the content and release of dopamine and I-methyl4-phenylpyridinium (Mpp+) in PCI 2 cells. Auton Autacoid Pharmacol 2002, 22(5-6):277-289.

44. Waters MD, Olden K, Tennant RW: Toxicogenomic approach for assessing toxicant-related disease. Mutat Res 2003, 544(23):4I5-424

45. Wetmore BA, Merrick BA: Toxicoproteomics: proteomics applied to toxicology and pathology. Toxicol Pathol 2004 32(6):619-642.

46. Tong $W$, Harris $S$, Cao $X$, Fang $H$, Shi L, Sun $H$, Fuscoe J, Harris $A$, Hong H, Xie Q, et al:: Development of public toxicogenomics software for microarray data management and analysis. Mutat Res 2004, 549(I-2):24I-253.

47. Yang YH, Dudoit S, Luu P, Lin DM, Peng V, Ngai J, Speed TP: Normalization for cDNA microarray data: a robust composite method addressing single and multiple slide systematic variation. Nucleic Acids Res 2002, 30(4):el 5.

48. Wren JD: Extending the mutual information measure to rank inferred literature relationships. BMC Bioinformatics 2004, 5(I): 145.

49. Wren JD, Garner HR: Shared relationship analysis: ranking set cohesion and commonalities within a literature-derived relationship network. Bioinformatics 2004, 20(2):19|-198.

50. Wren JD, Bekeredjian R, Stewart JA, Shohet RV, Garner HR: Knowledge discovery by automated identification and ranking of implicit relationships. Bioinformatics 2004, 20(3):389-398.

5I. Jiang PH, Motoo Y, Vaccaro MI, lovanna JL, Okada G, Sawabu N: Expression of vacuole membrane protein I (VMPI) in spontaneous chronic pancreatitis in the WBN/Kob rat. Pancreas 2004, 29(3):225-230.

52. Kokame K, Agarwala KL, Kato H, Miyata T: Herp, a new ubiquitinlike membrane protein induced by endoplasmic reticulum stress. J Biol Chem 2000, 275(42):32846-32853.

53. Dohn M, Jiang J, Chen X: Receptor tyrosine kinase EphA2 is regulated by p53-family proteins and induces apoptosis. Oncogene 200I, 20(45):6503-65I5.

54. Gotz ME, Double K, Gerlach M, Youdim MB, Riederer P: The relevance of iron in the pathogenesis of Parkinson's disease. Ann N Y Acad Sci 2004, I 0 I 2:193-208.

55. Dick RA, Kwak MK, Sutter TR, Kensler TW: Antioxidative function and substrate specificity of NAD(P)H-dependent alkenal/one oxidoreductase. A new role for leukotriene B4 I2hydroxydehydrogenase/ I 5-oxoprostaglandin I3-reductase. J Biol Chem 200I, 276(44):40803-40810.

56. Challen GA, Martinez G, Davis MJ, Taylor DF, Crowe M, Teasdale $\mathrm{RD}$, Grimmond SM, Little MH: Identifying the molecular phenotype of renal progenitor cells. J Am Soc Nephrol 2004, I5(9):2344-2357.

57. Doutheil J, Althausen S, Gissel C, Paschen W: Activation of MYDI 16 (gadd34) expression following transient forebrain ischemia of rat: implications for a role of disturbances of endoplasmic reticulum calcium homeostasis. Brain Res Mol Brain Res 1999, 63(2):225-232.

58. Kagedal K, Johansson U, Ollinger K: The lysosomal protease cathepsin $\mathrm{D}$ mediates apoptosis induced by oxidative stress. Faseb J 200I, 15(9): 1592-1594.

59. Garcia-Arumi E, Andreu AL, Lopez-Hellin J, Schwartz S: Effect of oxidative stress on lymphocytes from elderly subjects. Clin $\mathrm{Sci}$ (Lond) 1998, 94(4):447-452.

60. Bourke GJ, El Alami W, Wilson SJ, Yuan A, Roobol A, Carden MJ: Slow axonal transport of the cytosolic chaperonin CCT with Hsc73 and actin in motor neurons. I Neurosci Res 2002, 68(I):29-35.

61. Roobol A, Holmes FE, Hayes NV, Baines AJ, Carden MJ: Cytoplasmic chaperonin complexes enter neurites developing in vitro and differ in subunit composition within single cells. $J$ Cell Sci 1995, 108(Pt 4):| 477-I 488.

62. Cappelletti G, Incani C, Maci R: Involvement of tubulin in MPP+ neurotoxicity on NGF-differentiated PCI 2 cells. Cell Biol Int 1995, 19(8):687-93.

63. Zheng S, Chou AH, Jimenez AL, Khodadadi O, Son S, Melega WP, Howard BD: The fetal and neonatal brain protein neuronatin protects $P C I 2$ cells against certain types of toxic insult. Brain Res Dev Brain Res 2002, 136(2): 101-II0.

64. Myer DL, Bahassi el M, Stambrook PJ: The Plk3-Cdc25 circuit. Oncogene 2005, 24(2):299-305.

65. Shugart EC, Levenson AS, Constance CM, Umek RM: Differential expression of gas and gadd genes at distinct growth arrest points during adipocyte development. Cell Growth Differ 1995, 6(1 2): $154 \mid-1547$

66. Rees WD, Hay SM, Fontanier-Razzaq NC, Antipatis C, Harries DN Expression of the growth arrest genes (GAS and GADD) changes during organogenesis in the rat fetus. J Nutr 1999, I29(8): $1532-1536$.

67. Huang NK: Adenosine A2A receptors regulate oxidative stress formation in rat pheochromocytoma $\mathrm{PCI} 2$ cells during serum deprivation. Neurosci Lett 2003, 350(2): 127-|3|. 
68. Sykes DE, Weiser MM: Rat intestinal crypt-cell replication factor with homology to early S-phase proteins required for cell division. Gene 1995, 163(2):243-247.

69. Nowotny M, Bhattacharya S, Filipek A, Krezel AM, Chazin W, Kuznicki J: Characterization of the interaction of calcyclin (SI00A6) and calcyclin-binding protein. J Biol Chem 2000, 275(40):3||78-3||82.

70. Lesniak W, Swart GW, Bloemers HP, Kuznicki J: Regulation of cell specific expression of calcyclin (SIO0A6) in nerve cells and other tissues. Acta Neurobiol Exp (Wars) 2000, 60(4):569-575.

71. Stephenson A, Huang GY, Nguyen NT, Reuter S, McBride JL, Ruiz JC: snfllk encodes a protein kinase that may function in cell cycle regulation. Genomics 2004, 83(6): I I05-IIII5.

72. Teraoka $Y$, Naruse TK, Oka A, Matsuzawa $Y$, Shiina T, lizuka M, Iwashita $\mathrm{K}$, Ozawa A, Inoko $\mathrm{H}$ : Genetic polymorphisms in the cell growth regulated gene, SCI telomeric of the HLA-C gene and lack of association of psoriasis vulgaris. Tissue Antigens 2000, 55(3):206-2II.

73. Jiang B, Liu JH, Bao YM, An LJ: Hydrogen peroxide-induced apoptosis in pcl 2 cells and the protective effect of puerarin. Cell Biol Int 2003, 27(1 2): 1025-1031.

74. Tarabin $\mathrm{V}$, Schwaninger M: The role of NF-kappaB in 6-hydroxydopamine-and TNFalpha-induced apoptosis of PCI 2 cells. Naunyn Schmiedebergs Arch Pharmacol 2004, 369(6):563-569.

75. Stokes AH, Freeman WM, Mitchell SG, Burnette TA, Hellmann GM, Vrana KE: Induction of GADD45 and GADDI 53 in neuroblastoma cells by dopamine-induced toxicity. Neurotoxicology 2002, 23(6):675-684.

76. Paunesku T, Mittal S, Protic M, Oryhon J, Korolev SV, Joachimiak A, Woloschak GE: Proliferating cell nuclear antigen (PCNA): ringmaster of the genome. Int I Radiat Biol 200I, 77(10): 1007-102I.

77. Xiao G, Chicas A, Olivier M, Taya Y, Tyagi S, Kramer FR, Bargonetti J: A DNA damage signal is required for p53 to activate gadd45. Cancer Res 2000, 60(6): $17|1|-1719$.

78. Schena M, Shalon D, Davis RW, Brown PO: Quantitative monitoring of gene expression patterns with a complementary DNA microarray. Science 1995, 270(5235):467-470.

79. Johnson $\mathrm{K}$, Lin S: QA/QC as a pressing need for microarray analysis: meeting report from CAMDA'02. Biotechniques 2003:62-63.

80. Ivanov D, Dvoriantchikova G, Pestova A, Nathanson L, Shestopalov VI: Microarray analysis of fiber cell maturation in the lens. FEBS Lett 2005, 579(5): 1213-1219.

81. Ludwikow A, Gallois P, Sadowski J: Ozone-induced oxidative stress response in Arabidopsis: transcription profiling by microarray approach. Cell Mol Biol Lett 2004, 9(4B):829-842.

82. Noh HS, Lee HP, Kim DW, Kang SS, Cho GJ, Rho JM, Choi WS: A cDNA microarray analysis of gene expression profiles in rat hippocampus following a ketogenic diet. Brain Res Mol Brain Res 2004, I 29(I-2):80-87.

83. King HC, Sinha AA: Gene expression profile analysis by DNA microarrays: promise and pitfalls. Jama 2001, 286( I 8):2280-2288.

84. Lee CS, Han ES, Lee WB: Antioxidant effect of phenelzine on MPP+-induced cell viability loss in differentiated $\mathrm{PCI} 2$ cells. Neurochem Res 2003, 28(1 2):1833-184I.

85. Virmani A, Gaetani F, Binienda Z, Xu A, Duhart H, Ali SF: Role of Mitochondrial Dysfunction in Neurotoxicity of MPP+: Partial Protection of PCI 2 Cells by Acetyl-I-Carnitine. Ann N Y Acad Sci 2004, 1025:267-273.

86. Qing H, Xu H, Wei Z, Gibson K, Li XM: The ability of atypical antipsychotic drugs vs. haloperidol to protect $\mathrm{PCI} 2$ cells against MPP+-induced apoptosis. Eur I Neurosci 2003, I7(8): $1563-1570$.

87. Sheng G, Pu X, Lei L, Tu P, Li C: Tubuloside B from Cistanche salsa rescues the $\mathrm{PCI} 2$ neuronal cells from I-methyl-4-phenylpyridinium ion-induced apoptosis and oxidative stress. Planta Med 2002, 68(I I):966-970.

88. Quigney DJ, Gorman AM, Samali A: Heat shock protects PCI 2 cells against MPP+ toxicity. Brain Res 2003, 993(I-2): I33-139.

89. Iwaki K, Chi SH, Dillmann WH, Mestril R: Induction of HSP70 in cultured rat neonatal cardiomyocytes by hypoxia and metabolic stress. Circulation 1993, 87:2023-2032.

90. Mestril R, Dillmann WH: Heat shock and adaptive response to ischemia. Trend Cardiovasc Med 199I, I:240-244.
9I. Bagchi D, Bagchi M, Hassoun EA, Stohs SJ: In vitro and in vivo generation of reactive oxygen species, DNA damage and lactate dehydrogenase leakage by selected pesticides. Toxicology 1995 , 104:129-140.
Publish with Biomed Central and every scientist can read your work free of charge

"BioMed Central will be the most significant development for disseminating the results of biomedical research in our lifetime. "

Sir Paul Nurse, Cancer Research UK

Your research papers will be:

- available free of charge to the entire biomedical community

- peer reviewed and published immediately upon acceptance

- cited in PubMed and archived on PubMed Central

- yours - you keep the copyright 